Editorial II

\title{
Otolaryngology and Head and Neck Surgeries during Pandemic era - How Make them Safer
}

\author{
Fatima Cristina Mendes de Matos ${ }^{1(1)}$ Geraldo Pereira Jotz ${ }^{2}$ (1) \\ ${ }^{1}$ Head and Neck Department, Universidade de Pernambuco (UPE). \\ Recife, PE, Brazil \\ ${ }^{2}$ Dean of Innovation and Institutional Affairs, Universidade Federal do \\ Rio Grande do Sul (UFRGS). Porto Alegre, RS, Brazil
}

Int Arch Otorhinolaryngol 2021;25(4):e481-e482.

In the first quarter of 2020, we had many questions and few answers. We did not know how COVID-19 could impact our patients and our surgical teams. The speed at which scientific papers were published helped us to understand COVID-19 and how we can perform our surgical procedures. One important lesson is that it is imperative to follow universal pandemic precautions, including appropriate personal protective equipment (PPE), because of the high risk for SARS$\mathrm{CoV}-2$ infection due to aerosol and droplet exposure during examinations and procedures within the head and neck region and airway. We will address important topics that must be taken into account in the daily practice of otolaryngologists and head and neck surgeons.

\section{How Can We Reduce the Chances of Contamination?}

We need to take care not only in the operating room. Our exposure during examination brings us high risk because of aerosol generation. For this reason, also in offices, we must use PPEs, like N95, face shields, goggles, and cloaks - everything that helps us to minimize the risk of contact with the virus. $^{1,2}$

Before patient care, it is essential that we trace epidemiological profiles, by applying a questionnaire to evaluate patients that had or are with potential infections. Many health institutions and also the Health Ministry had designed questions to screen suspicious cases. ${ }^{3}$ Brazilian Society of Surgical Oncology recommends preoperative self-isolation to reduce the chances of surgical procedures during the incubation period, especially for patients who will undergo major surgery or have comorbidities. Preoperative self-isolation also may reduce the chances of a patient infecting the surgical team, especially in head and neck, thoracic, and other high-risk aerosol-generating procedures. ${ }^{4}$

Address for correspondence Geraldo Pereira Jotz, MD, PhD, Rua Sarmento Leite, 500, Prédio do ICBS, Porto Alegre, RS, 90050170 Brazil

(e-mail: geraldo.jotz@terra.com.br).
In case of availability of the RT-PCR, we suggest that it be performed 24-48 hours before surgery and after at least 7 days of self-isolation. Considering that RT-PCR has a false negative rate of $20-30 \%,{ }^{5}$ it is possible to affirm that in combination with the clinical screening, likely $<10 \%$ of the SARS-CoV-2-infected patients will be inadvertently operated during the incubation period. The Fleischner Society recognized that in highly prevalent areas, an additional CT should be used as a screening tool either as a stand-alone or as an adjunct to real-time polymerase chain reaction (RT-PCR) to exclude occult infection prior to surgery or intensive immunosuppressive therapies. ${ }^{6}$ In the Japanese survey, $90 \%$ of head and neck cancer specialists perform preoperative $\mathrm{CT}$, at least as frequently as possible. ${ }^{7}$ Following the same path, Brazilian Head and Neck Society guides associates to perform RT- PCR and Chest CT-scan 48 hours before surgeries. ${ }^{8}$

We consider that in the absence of RT-PCR in highprevalence areas, it is acceptable to offer to perform CT 24-48 hours before hospitalization in high-risk surgical candidates, once it is possible to diagnose $54 \%$ of the asymptomatic cases of COVID-19. If the patient has an indication of a CT for cancer staging, this strategy may be even more interesting if performed 2 days before surgery as it can work for cancer staging and COVID-19 screening at the same time. ${ }^{9}$

In the operating room, the universal use of smoke evacuators to suction away the smoke plumes generated by electrocautery has been encouraged to minimize the risk of exposure to health care personnel of aerosolized tissue ${ }^{10}$. To perform surgery and laryngoscopy, use rooms with negative pressure in addition to high-efficiency particulate absorbing (HEPA) filters in air conditioning systems. $8,11,12$

Surgical patients have unique risks due to COVID-19. Operating on patients with either asymptomatic or symptomatic COVID-19 increases the risk for perioperative morbidity and mortality. In a case-control analysis from Italy,

(c) 2021. Fundação Otorrinolaringologia. All rights reserved.

This is an open access article published by Thieme under the terms of the Creative Commons Attribution-NonDerivative-NonCommercial-License, permitting copying and reproduction so long as the original work is given appropriate credit. Contents may not be used for commercial purposes, or adapted, remixed, transformed or built upon. (https://creativecommons.org/ licenses/by-nc-nd/4.0/)

Thieme Revinter Publicações Ltda., Rua do Matoso 170, Rio de Janeiro, RJ, CEP 20270-135, Brazil 
Doglietto et al showed that the 30-day risk of mortality for patients with COVID-19 undergoing surgery $(n=41)$, compared with patients without COVID-19 $(n=82)$, was significantly higher (19.51\%vs $2.44 \%$; odds ratio [OR], 9.5 [95\% CI, 1.8-96.5]). The odds for perioperative pulmonary complications were also significantly higher (OR,35.6), as were the odds of thrombotic complications (OR, 13.2)..$^{13}$

A retrospective cohort study with 34 operative patients who developed COVID-19 pneumonia shortly after surgery found that $44.1 \%$ needed the Intensive Care Unit (ICU), and the mortality rate was $20.5 \%$. Considering only the patients who have had cancer surgery, the mortality rate was $44.4 \%{ }^{14}$

The American Society of Anesthesiologists (ASA) and Anesthesia Patient Safety Foundation (APSF) wrote the parameters to the exact time for elective surgery after recovery from SARS-CoV-2 infection. ${ }^{15}$ They used categories that were based on both symptoms and severity. The suggested waiting times from the date of COVID-19's diagnosis are as follows:

1) Four weeks for an asymptomatic patient or after recovery from mild, non-respiratory symptoms.

2) Six weeks for a symptomatic patient (e.g., cough, dyspnoea) who did not require hospitalization.

3) Eight to ten weeks for a symptomatic patient who is diabetic, immunocompromised, or hospitalized.

4) Twelve weeks for a COVID-19's patient who was admitted to the ICU.

More recently, two cooperative groups (CovidSurg and Global Surg), determine the optimal duration of planned delay before surgery in patients who have had SARS-CoV-2 infection. When possible, surgery should be delayed for at least 7 weeks following SARS-CoV-2 infection. Patients with ongoing symptoms $\geq 7$ weeks from diagnosis may benefit from further delay. In critically ill patients that went to ICU, consider delaying the surgery for 12 weeks. ${ }^{16}$

Another important aspect is surgery after vaccination. The Royal College of Surgeons of England advises in their Vaccinated patients' guidance that non-urgent elective surgery can also take place soon after vaccination. There is some rationale for separating the date of surgery from vaccination by a few days (at most 1 week) so that any symptoms such as fever might be correctly attributed to the consequences of either vaccination or the operation itself. ${ }^{17}$

This is a new era where high heels and expensive ties do not matter! We are all the same, with our N95 masks and face shields. Many procedures will be incorporated into our routine to make them safer for surgical teams and patients.

\section{Conflict of Interest}

The authors have no conflict of interest to declare.

\section{References}

1 Howard BE. High-Risk Aerosol-Generating Procedures in COVID19: Respiratory Protective Equipment Considerations. Otolaryngol Head Neck Surg 2020;163(01):98-103
2 Mick P, Murphy R. Aerosol-generating otolaryngology procedures and the need for enhanced PPE during the COVID-19 pandemic: a literature review. J Otolaryngol Head Neck Surg 2020;49(01):29

3 Ministério da Saúde. Diretrizes para diagnóstico e tratamento da COVID-19. Brasil. [cited 2021 Sept]. Available from: https://www. gov.br/saude/pt-br

4 Wainstein AJA, Drummond-Lage AP, Ribeiro R, et al. Risks of COVID-19 for surgical cancer patients: The importance of the informed consent process. J Surg Oncol 2020;••;;. Doi: 10.1002/ so. 26065

5 Li Y, Yao L, Li J, et al. Stability issues of RT-PCR testing of SARS-CoV2 for hospitalized patients clinically diagnosed with COVID-19. J Med Virol 2020;92(07):903-908

6 Rubin GD, Ryerson CJ, Haramati LB, et al. The role of chest imaging in patient management during the COVID-19 pandemic: a multinational consensus statement from the Fleischner Society. Chest 2020;158(01):106-116

7 Ota I, Asada Y. The impact of preoperative screening system on head and neck cancer surgery during the COVID-19 pandemic: Recommendations from the nationwide survey in Japan. Auris Nasus Larynx 2020;47(04):687-691

8 SBCCP - Sociedade Brasileira de Cirurgia de Cabeça e Pescoço Brasil. [cited 2021 Sept]. Available from: http://sbccp.org.br/

9 Inui S, Fujikawa A, Jitsu M, et al. Chest CT findings in cases from the cruise ship "diamond princess" with coronavirus disease 2019 (COVID-19). Radiol Cardiothorac Imaging 2020;2(02):e200110. Doi: $10.1148 /$ ryct.2020200110

10 Livingston EH. Surgery in a time of uncertainty: a need for universal respiratory precautions in the operating room. JAMA 2020;323(22):2254-2255

11 Oliveira MC, Gabardo BA, Martins CC, et al. Recomendações AMIB sobre controle sanitário e estratégias de contingenciamento das unidades de terapia intensiva para atendimento dos pacientes com coronavírus. AMIB - Associação de Medicina Intensiva Brasileira. [cited 2021 Sept]. Available from: https://www.amib. org.br/fileadmin/user_upload/amib/2020/marco/28/VJS_280320_ 21H40_RECOMENDACOES_AMIB_SOBRE_CONTROLE_SANITARIO_E_ESTRATEGIAS_DE_CONTINGENCIAMENTO_DAS_UNIDADES_ DE_TERAPIA_INTENSIVA_PARA_ATENDIMENTO_DOS_PACIENTES_ COM_CORONAVIRUS.pdf

$12 \mathrm{CDC}$ - Centers for Disease Control and Prevention. Ventilation in Buildings. [cited $2021 \mathrm{Sept}$ ]. Available from: https://www.cdc.gov/coronavirus/2019-ncov/community/ventilation.html

13 Doglietto F, Vezzoli M, Gheza F, et al. Factors Associated with surgical mortality and complications among patients with and without coronavirus disease 2019 (COVID-19) in Italy. JAMA Surg 2020;155(08):691-702

14 Lei S, Jiang F, Su W, et al. Clinical characteristics and outcomes of patients undergoing surgeries during the incubation period of COVID-19 infection. EClinicalMedicine 2020;21:100331

15 SBA - Sociedade Brasileira de Anestesiologia. Declaração Conjunta da Sociedade Americana de Anestesiologistas e Fundação para a Segurança do Paciente de Anestesia a respeito de Cirurgia Eletiva e Anestesia para Pacientes pós-infecção Covid-19. [cited 2021 Sept]. Available from: https://www.saerj.org.br/wp-content/uploads/ 2020/12/artigo-cirurgia-eletiva-pos-covid-portugues-FINAL-1-3-1. pdf

16 COVIDSurg Collaborative GlobalSurg Collaborative. Timing of surgery following SARS-CoV-2 infection: an international prospective cohort study. Anaesthesia 2021;76(06):748-758. Doi: 10.1111/anae. 15458

17 UK Surgical Royal Colleges. Vaccinated patients guidance. [cited 2021 Sept]. Available from: https://www.rcseng.ac.uk/coronavirus/ vaccinated-patients-guidance/ 